\title{
Development of Problem Based Learning Tools to Improve Visual Thinking and Self Efficacy of Seventh Grade Junior High School Students in Besitang
}

\author{
Meli Rama Yunita \\ Education of Mathematic, Post Graduate \\ State University of Medan \\ Medan, Indonesia \\ meliramayunita22@gmail.com
}

\author{
Edy Surya \\ Department of Mathematics Science Faculty \\ State University of Medan \\ Medan, Indonesia \\ line 4-e-mail address if desired
}

\author{
Edi Syahputra \\ Department of Mathematics Science Faculty \\ State University of Medan \\ Medan, Indonesia
}

\begin{abstract}
This study aimed to describe how: 1) the validity, practicality and effectiveness of learning materials using problem based learning, and 2) the improvemet of visual thinking ability and self afficacy against mathematics by using the learning materials. This type of research is development research. Development model used promblem based learnings development model which consist of ten steps. The research resulted products are lesson plan, teachers book, students book, students worksheet, tests visual thinking and self efficacy questionnaire. The first trial took place in class VII 1 and the second trial in class VII 2 SMP swasta RGM Besitang. Result of these research showed that : 1) learning materials were valid, both in content and construct validity, 2) learning materials were practical to be used, reviewed from validators assessment and students positive responses, 3) learning materials were effective, reviewed from mastery of learning and students activity and students positive responses, 4) increasing of students visual thinking ability was on medium category and 5) there was increase in students self efficacy against mathematics of trial 1 to trial 2.
\end{abstract}

Keywords- Developing Learning Materials, Problem Based Learning, Visual Thinking Ability, Student Self Efficacy

\section{INTRODUCTION}

Mathematics as one of the subjects which constitutes basic science has an important and beneficial role for the development of science and technology. Based on the Republic of Indonesia Minister of Education Regulation No. $22 / 2006$, it is explained that the purpose of learning mathematics in schools is so that students have the following abilities,(1) Understanding mathematical concepts, explaining the interrelationships between concepts and applying concepts or algorithms, flexibly, accurately, efficiently, and precisely, in problem solving,(2) Using reasoning on patterns and properties, doing mathematical manipulation in making generalizations, compiling evidence, or explaining mathematical ideas and statements, (3) Solve problems that include the ability to understand problems, design mathematical models, solve models and interpret the solutions obtained, (4) Communicate ideas with symbols, tables, diagrams, or other media to clarify the situation or problem, (5) Having an attitude of appreciating the usefulness of mathematics in life, namely having curiosity, attention, and interest in learning mathematics, as well as being tenacious and confident in problem solving [1].

The importance of mastery of mathematics for students is not in line with the quality of mastery of mathematics. But in fact many students who have difficulty in learning mathematics, are less interested and always consider mathematics as a difficult subject, causing fear to learn mathematics which causes low learning outcomes. Student mathematics learning outcomes to date are still far to be expected as expressed by [2] that it is seen from the results of learning mathematics students from elementary school to senior high school are always below other fields of study.

In order for the learning process to achieve the expected learning objectives, it is necessary to develop learning tools that are appropriate to the model or approach applied. In developing learning tools, the preparation of learning tools should be able to facilitate students in understanding the material. Teachers as education implementers are required to have tools in implementing learning to maintain general goals and specific objectives so that the educational process runs in accordance with the expectations of the government

According to Sodijarto [3], the professional abilities of teachers include: "(1) designing and planning learning programs, (2) developing learning programs, (3) managing the implementation of learning programs, (4) evaluating learning processes and outcomes, (5) diagnosing factors that affect the success of the learning process, (3) managing learning 
programs, (4) assessing the processes and learning outcomes, (5) diagnosing factors that affect the success of the learning process, (3) learning. These professional abilities are part of the competence teachers have. The same thing was conveyed in the journal Learning desired by teachers is not dominant, but is emphasized by the interaction between teachers and students. The learning process will be better if there is more interaction between students and teachers. It is also hoped that teachers can design appropriate education since they are within the environment in the educational environment to achieve learning objectives.

Development of learning tools is a series of processes or activities carried out to produce a learning device based on existing development theories. So the development of learning tools is a process carried out to produce a series of learning tools that are used by teachers and students in the learning process in class. A series of learning tools that must be prepared by a teacher in dealing with learning in class, including: (a) Learning Implementation Plan (RPP); (b) Student Books; (c) Teacher's book (BG); (d) Student Activity Sheet (LAS); (e) Learning ability test. All subjects can be developed learning tools, mathematics is no exception.

Mathematics is formed from human experience in an empirical world. Then the experience is processed in the world of ratios, processed analytically by reasoning in the cognitive structure so that mathematical concepts are formed so that mathematical concepts formed are easily understood by others and can be manipulated appropriately, then use mathematical language or notation mathematics of global value (universal). The concept of mathematics is obtained because of the thought process, because logic is the basis of the formation of mathematics. However, in reality mathematics learning in Indonesia is still unable to compete internationally. This is shown by the results of the 2015 PISA (Program for International Student Assessment) study which shows that Indonesia can only rank 69 th out of 76 countries [4].

According to [5] the learning process in the classroom still lacks attention. Not all teachers have innovated the core learning activities. This has led to learning that is still lacking by students, so that students' enthusiasm is always too enthusiastic about learning mathematics.

Learning tools used to achieve planned learning objectives should be developed according to student needs. The tools developed are oriented to the problem-based learning model that can facilitate students to improve students' thinking abilities, enable students to learn, give students the opportunity to build their own knowledge, student-centered learning and adapted to the objectives to be achieved.

The use of contextual problems in problem-based learning models makes learning more meaningful. said that in problembased learning (PBL) describes a learning environment where problems encourage learning, learning begins with problems that must be solved, and problems raised in such a way that students need to gain new knowledge before they can solve problems with looking for one correct answer, students interpret problems, gather necessary information, identify possible solutions, evaluate options, and present conclusions.

According to Muslimin [6], Problem based learning is an approach to learn students to develop thinking skills and problem solving skills, learn the role of authentic adults and become independent learners. Problem based learning is not designed to help teachers provide as much information as possible to students, but problem based learning is developed to help students develop thinking skills, problem solving and intellectual skills, learn various adult roles through engaging them in real experiences and becoming learning independent.

Based on the opinions mentioned above can be taken several important things related to problem-based learning, namely, 1) giving more free space for children to explore the ability to think to find concepts, 2) effectively used for developing students' thinking abilities, 3) arousing interest and make students have a better focus in understanding and improving student performance, 4) student collaborative activities and student activities in the classroom look better and allow for dynamic interaction between teacher and student, student and student, 5) increase student motivation and self-confidence in learning, critical abilities and teamwork.

Visual representation is an important part in solving mathematical problems. conveyed the importance of visualization in solving mathematical problems.Visualization has an important role in thinking development, mathematical comprehension, and the transition thinking of concrete to abstract thinking related to mathematical problem solving.Visualization has an important role in the development of thinking, understanding mathematics, and the transition of thought for abstract thinking related to mathematical problem solving.

In learning mathematics requires the ability to think visually (visual thinking). Visual thinking (Visual Thinking) can be one alternative to facilitate students in learning mathematics. This is in line with what was raised by Surya which states that students usually have difficulty bridging informal knowledge to school mathematics. Students need special guidance and assistance in the form of visual thinking (Visual Thinking) of what they mean or think so that they can be visualized in the form of idea structures, ideas can be numbers, symbols, pictures, diagrams, model explanations, paintings that can help students in the learning process and solving their mathematical problems.

According to[7] Visual Thinking is an active thinking and analytical process for understanding, interpreting and producing visual messages, the interaction between seeing, imagining, and describing as goals and can be used, such as verbal thinking.

To help students develop visual thinking abilities, the teacher must first pay attention to the factors that influence students' choices in the problem solving method of the process and the role students use in visualizing mathematical problem solving. If visualization is at the core of mathematical problem solving, it is very important that both teachers and students see the role of visualization and use it to help them in their process of solving problems.

If students have mathematical visual thinking ability, of course students will be easy to represent problems and solve mathematical problems, represent mathematical problems in the form of images, graphs, tables, symbols, patterns, mathematical equations and so on. but in reality the ability of visual representation of students' thinking is still low. This can be seen from observations made by researchers. Researchers 
raised the problem with Raja Garuda Mas Besitang junior high School students.

The problems raised by students are :

A block frame model is made of wire with length $(x+5)$ and width $(\mathrm{x}-2) \mathrm{cm}$ and height $\mathrm{x} \mathrm{cm}$. the total length of the wire used cannot be $156 \mathrm{~cm}$.

1) Write down what is known in the problem above?

2) Arrange the inequality in the form of $x$

3) Determine the value of $x$

Researchers conducted the first experiment by giving the questions above to 28 students of the Raja Garuda Mas Besitang Private VIIISMP class. This VIII grade student already got flat material and a linear equation of one variable in class VIII. However, only 3 students who meet and can represent the results of visualization in accordance with the expectations of researchers and besides can not yet visualize and represent it correctly. Here are the students' answers

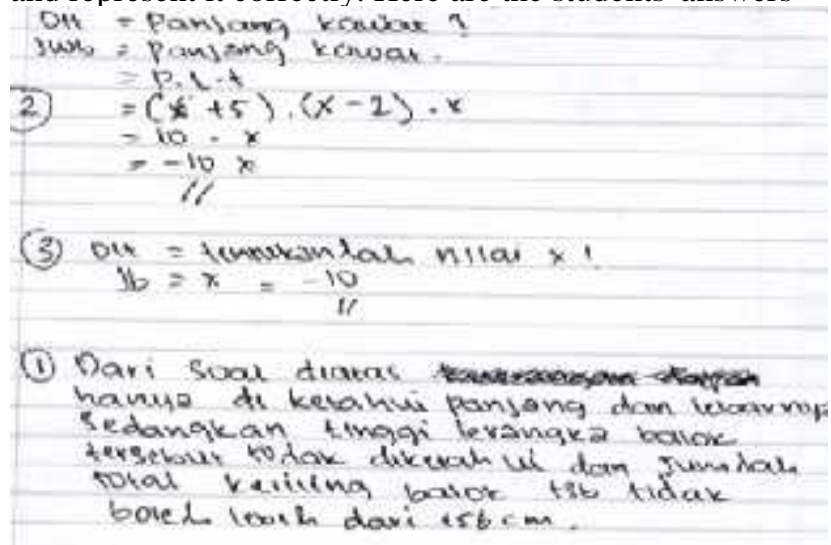

Fig. 1. Student Answers on the Representation of Visual Thinking problems

From the picture above shows students do not understand the problem in the given problem, unable to link between being asked with alternative problems, students do not understand the problem, so they are unable to make a mathematical inequality model so students cannot represent the problem correctly. Students will be able to solve the above problems if he is able to understand the problem by writing down what is known in the problem so that it will make it easier for students to understand the problem, visualize the problem in the form of linear equations and relate it in the form of linear inequalities of one variable. After students have been able to put problems into mathematical equations students can find the value of $\mathrm{x}$. Each individual might be different in visualizing. From this we will know the visualization ability of a student at that level. From experiments conducted by researchers showed the low ability of students' representation of visual thinking

In addition to the ability of visual representation of mathematical thinking. Students' self-efficacy abilities are also important. Individuals with high self-efficacy are committed to solving problems and will not give up when finding that the strategies provided are not successful. According to[8], individuals who have high self-efficacy will be very easy in facing challenges, individuals do not feel doubtful because they have full trust in their drastic abilities. So it can be said that individuals with high self-efficacy also have the ability to think critically.

Given the importance of student self-efficacy, self-efficacy should be developed in students. The achievement of students 'mathematical self-efficacy can be known by conducting observations and interviews in the process of learning mathematics and self-efficacy scale, here the researchers see the achievement of self-efficacy in this study is interpreted as students' confidence in their ability to represent and solve in a mathematical problem. This means that when a student is given a problem he can state or believe himself about his ability to solve the problem. But the fact of proving students 'self-efficacy is still low can be seen from observational data and interviews with mathematics subject teachers who teach in Raja Garuda Private Middle School Mas Besitang argued, $\mathrm{He}$ stated that students' self-efficacy abilities were still low this could be seen when working on student practice questions more give up quickly when faced with difficult problems, besides that students are also not sure of the answers they get, and when one of the themes presents the answers in front of the class the other students are reluctant to respond to problems due to doubt about their own abilities. This all indicates the ability of students' self efficacy is low.

Based on the description above, researchers are interested in conducting a study entitled "Development of Problem Based Learning Tools to Improve Visual Thinking Ability and Self Efficacy of sevent grade students of Raja Garuda Mas junior high School"

\section{METHOD}

research categorized into types of Research Development (Development Research). The learning device development model in this study uses 4D [9]. The learning tool developed is oriented to problem based learning on the material of one variable linear equation VII in junior high school. Learning tools developed include student books, teacher books, lesson plans (RPP) and student worksheets (LKS). In addition, in this research an instrument of visual thinking abilities self-efficacy abilities, validation sheets, observation sheets, and questionnaires will be prepared.

This research is divided into two stages, the first stage is the development of learning tools. Development of learning tools which include: (1) the validity of the Teacher's Book; (2) the validity of Student Books; (3) the validity of LAS; (4) the validity of the instrument of the ability of Visual Thingking Representation. The second stage is the implementation of learning tools that have been validated to see their practicality and effectiveness

The development model used to develop the learning tools in this study is a modification of the Thiagarajan, Semmel and Semmel models known as the 4-D (Four D Mode) model which consists of 4 stages of development namely the stage definition (define), design (design), development (develop) and dissemination (disseminate) . 


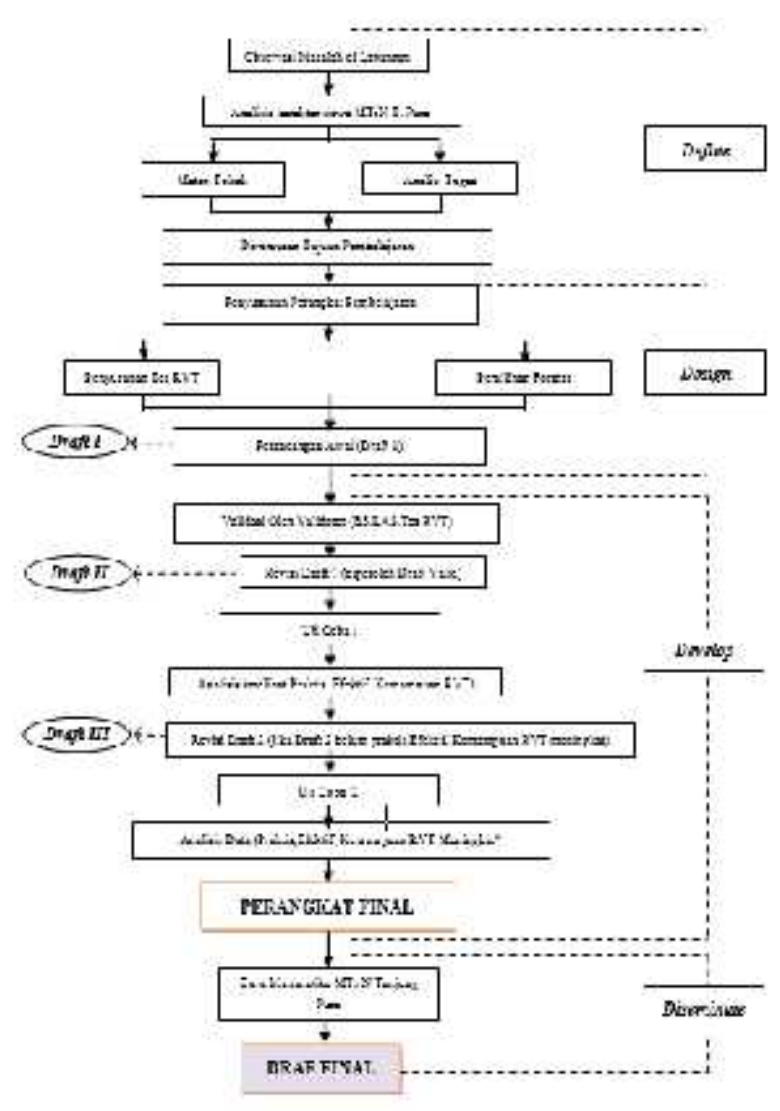

Fig. 2: Chart for developing 4-D model learning tools

The trial design that will be used in the development of the instrument is One - group pretest - posttest design. As follows

\begin{tabular}{|lrrr|}
\hline Tes & & Perlakuan & Tes \\
$\mathrm{T}$ & $\mathrm{x}$ & $\mathrm{T}$ & \\
\hline
\end{tabular}

Eplanation :

$\mathrm{T}_{1}=$ Pre-test

$\mathrm{T}_{2}=$ Post - test

$\mathrm{X}=$ Treatment of learning based on contextual approach.

\section{RESULTS AND DISCUSSIONS}

The validity of the device by experts meets valid criteria and can be used in trials. In trial I, the device was fulfilled practically, but it did not meet its effectiveness, but there was an increase in the ability of visual thinking representation. In trial 2, practical, effective and fulfilling criteria for visual thinking were fulfilled.

In line with these results, research conducted by Sakinah (2012: 150) There are differences in problem solving abilities taught by using problem-based learning tools. Overall it can be seen from the post-test students who were taught using a problem-based learning device was higher (86.60) compared to the pre-test of students before using a problem-based learning device (47.47), on the fractional material class $\mathrm{V}$ MIN. Thus it appears that the use of problem-based learning tools is effective in increasing problem solving abilities. This difference is caused by the teacher using a learning tool which is a set of learning resources that allows teachers and students to learn with a problem based learning approach.

Learning using PBM teaches students to gain their own experiences. This in accordance with the theory of constructivism learning is basically an explanation of how learning occurs or how information is processed in the minds of students. From a pedagogical point of view, the Problem Based Learning Model (Problem Based Learning) is based on the theory of constructivism with:( a) Understanding is obtained from interactions with problem scenarios and learning environments. (b) Struggling with problems and the process of problem inquiry creates cognitive dissonance that stimulates learning. (c) Knowledge occurs through a collaborative process of social negotiation and evaluation of the existence of a point of view. Learning Theory Jerome S. Bruner says the discovery method is a method by which students rediscover, not discover anything completely new. Learning discovery in accordance with the active search for knowledge by humans, by itself gives better results, trying to find solutions to their own problems and supported by the accompanying knowledge, and produce knowledge that is truly meaningful.

Learning using PBM teaches students to gain their own experiences. This in accordance with the theory of constructivism learning is basically an explanation of how learning occurs or how information is processed in the minds of students. From a pedagogical point of view, the Problem Based Learning Model (Problem Based Learning) is based on the theory of constructivism with characteristics [10] :( a) Understanding is obtained from interactions with problem scenarios and learning environments. (b) Struggling with problems and the process of problem inquiry creates cognitive dissonance that stimulates learning. (c) Knowledge occurs through a collaborative process of social negotiation and evaluation of the existence of a point of view. Learning Theory Jerome S. Bruner says the discovery method is a method by which students rediscover, not discover anything completely new. Learning discovery in accordance with the active search for knowledge by humans, by itself gives better results, trying to find solutions to their own problems and supported by the accompanying knowledge, and producing knowledge that is truly meaningful [11]. The results of this study are also in line with Ronis in [12] states that conventional teaching and learning is not bad but not enough to develop higher-order thinking skills such as problem solving skills. As a result, students are rarely included in problem solving abilities and teachers pay less attention in making learning material. Then, it appears that the teacher needs to know and apply a learning approach that can support and facilitate students' mathematical understanding and mathematical representation. In order for the learning process to achieve the expected learning objectives, it is necessary to develop learning tools that are appropriate to the model or approach applied. In the development of learning tools, the preparation of learning tools should make it easier for students to understand the material. The matter with the solar above, Hutagaol found the results of research showing contextual learning can improve the mathematical representation ability of junior high school students. Learning outcomes of students 
who get learning by using contextual learning, the ability of representation is better than the learning outcomes of students who use conventional learning.

To improve the ability of visual representation of thinking the teacher must be able to use a learning model that can improve high-level abilities, students are faced with problems to find concepts or conclusions. in line with the research of [13] said that in problem-based learning (PBL) describes a learning environment in which problems encourage learning, learning begins with problems that must be solved, and problems raised in such a way that students need to gain new knowledge before they can solving problems by finding one correct answer, students interpreting problems, gathering information needed, identifying possible solutions, evaluating options, and presenting conclusions.

In line with the above solar, [14] found research results that showed contextual learning can improve the mathematical representation ability of junior high school students. Learning outcomes of students who get learning by using contextual learning, the ability of representation is better than the learning outcomes of students who use conventional learning

[15] in their research conducted at SMP Negeri 2 Tanjung Pura stated that the problem solving process by using problem-based learning models was better than expository learning. Based on the results of this study, researchers also suggest that problem-based learning models can be used as alternatives for teachers to achieve high student logical reasoning competence

\section{CONCLUSIONS}

Based on the results of the analysis and discussion in this study, the following conclusions are presented:

1. Problem-based learning tools developed meet valid criteria.

2. Problem-based learning tools developed meet practical criteria. The practicality criteria are reviewed from: (1) the validator's evaluation of the learning kit as a whole is good and can be used with a little revision; (2) the implementation of the learning tools in trial 2 reached $85.14 \%$ in the good category.

3. Problem-based learning tools developed meet effective criteria. Effective criteria in terms of: (1) completeness of student learning outcomes classically with a minimum value of 2.67 has reached $86.67 \%$ in the trial 2; (2) student activities on all aspects observed are within the ideal time tolerance limits set; and (3) many students who gave positive responses to the activities and learning tools developed reached $90.00 \%$.

4. Improvement of students' visual thinking abilities using problem-based learning tools developed in the material equation and linear inequality of one variable in terms of the percentage of achievement of $9.97 \%$. The completeness of the ability of students in tryout 1 of 76.7 increased to 86.67 in tryout 2 .

5. The increase in students' self-efficacy is obtained from the total average of self-efficacy in trial 1 of 76.37 and trial 2 of 77.57 .

\section{References}

[1] Rohman, M dan Amri, S. 2013. Strategi dan Desain Pengembangan Sistem Pembelajaran. Jakarta: Prestasi Pustaka.

[2] Hasraratuddin. 2013 Membangun karakter melalui pembelajaran matematika, Paradikma Vo. 6 Nomor 2. ISSN 1978-8002.

[3] Wiyana. 2013. Pengaruh Pengetahuan KTSP dan Pendidikan Terhadap Kemampuan Menyusun RPP Guru SDN Jatiyoso Tahun 2011/2012. $\begin{array}{llll}\text { Jurnal Teknologi Pendidikan, } 1 & \text { (2): } & \text { 239-248 }\end{array}$ (http://jurnal.pasca.uns.ac.id

[4] Ramadanti, R. (2016). Peringkat Pendidikan Indonesia masih Rendah. http://www.pikiran-rakyat.com/pendidikan/2016/06/18/peringkatpendidikan-indonesia-masih-rendah-372187.

[5] Hosnan. 2014. Pendekatan Saintifik dan Kontekstual dalam Pembelajaran Abad 21. Jakarta:Galian Indonesia.

[6] Boud, Felletti. (2000), The Challenge of Problem Based Learning, London :Kogan Page.

[7] Surya, E. \& Syahputra, E. 2017. Improving High-Level Thinking Skills By Development Of Learning PBL Approach On The Learning Mathematics For Senior High School Students. Published by Canadian Center of Science and Education.International Education Studies; Vol. 10, No. 8; 2017.ISSN 1913-9020 E-ISSN 1913-9039

[8] Bandura, A. 1997. Self Efficacy: The Exercise of control. New York: W. H. Freeman and Company.

[9] Thiagarajan, S. Semmel, D.S. Semmel, M. (1974). Instructional Development for Training Teachers of Exceptional Children. A Sourse Book. Blomington: Central for Innovation on Teaching The Handicapped.

[10] Rusman. 2011. Model-Model Pembelajaran : Mengembangkan Profesionalisme Guru. Jakarta: Rajawali Pers

[11] Dahar, R. W. 2011. Teori-Teori Belajar \& Pembelajaran. Jakarta : Erlangga

[12] Minarni, A. Napitulu, E. \& Husein, R. 2016. Mathematical Understanding And RepresentationAbility Of Public Junior High School In North Sumatra. Journal on Mathematics Education. Volume 7, No. 1, January 2016, pp. 43-56. ISSN 2087-8885.

[13] Surya, E. 2013. Peningkatan Kemampuan Representasi Visual Thinking pada Pemecahan Masalah Matematis dan Kemandirian Belajar Siswa SMP melalui Pembelajaran Kontekstual Universitas Pendidikan Indonesia. Disertasi. Tidak dipublikasikan. Bandung: PPs Universitas Pendidikan Indonesia.

[14] Hutagaol, Kartini. 2013. Pembelajaran Konteks tual Untuk Meningkatkan Kemampuan Representasi Matematis Siswa Sekolah Menengah Pertama. Infinity Jurnal ilmiah Program Studi Matematika STKIP Siliwangi Bandung, Vol 2, No.1, Februari 2013.

[15] Mukthar \& Syahputra, E. (2014). Perbedaan Kemampuan Penalaran Logis Siswa pada Pendekatan Pembelajaran Berbasis Masalah dan Pembelajaran Ekspositori di SMP Negeri 2 Tanjung Pura. Jurnal pendidikan matematika paradigma. Vol. 7 No.1 Edisi April 2014 